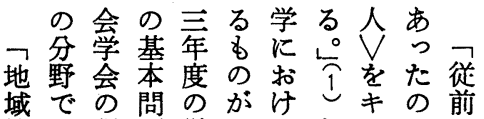

域で課題学なるとイに前

会主題岕会い貊・対農

会要研 党設で地指ュし村

教な究が立は域摘 $=$ て社

充問刊云な社はッ、会

$\leftarrow$ 題地行 $\vec{\bigcirc}$ 小会、卜戦学

に亡域さ周。充お之後は

関乙或れ年そ教おし段意

すて祬て記し充また段識

るク会以念てしか意階論

研口落事々にな識での

究 1 謷、業の関断研の導

艻ズ育あの研导定究、都入

高方論るひ究るに市と

度ア論以と方研す調社展

経ッ再はつ法究ぎ查会開

済プ再同とのにる学に

成さ検年し科つとをのか

は

じ

め

都

に

市

近

郊

農

村

に

お

け

長れ討度て学いし起不な

にて芆の $\neg$ 的 $\tau \tau$ 点夕り、

伴き旦教有いす

心元以本笲効学教々禁

只降教社性は充しは欲、

都る充会出肯社て公的

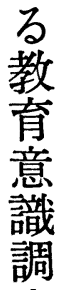

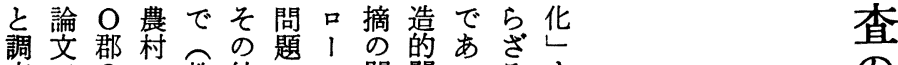

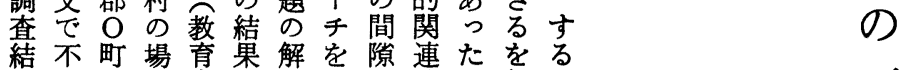

果十の合意の明批に性。得旦

の分調门識一に判あをわな本

分に查、研部向的る追れいの

析しを斻究はけに実求わの地

をか教出に共て継証しれは域

中述㻆こ扣同切承的ては、湖 心べ意のけ研りし研き戦そあ にら識論る究拓つ究た後のっ れ解稿生者くつでが速て 社な明で活のべすあ謴度、

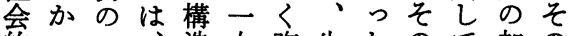
的っ二、造人昨生たのて加の 価た事々論矢年活。方种方 值教例の的野来構そ法地度法 志育と共アが共造の論域性論 向意し同プす同論中は社か的 性識て研口で研的で、会ら混 の分紹究 1 に究了社先云迷 タ析介にチ発をプ会のとるの イのし基|表行口構奥意中 プ方穵しつ１造田教味を と法特く都ててチ論氏育でか 教的に福市いきを的氏しはい 意組野県郊のた謷プのの指構然ぐ 
圀 1 O 郡 $\mathrm{O}$ 町 略 図

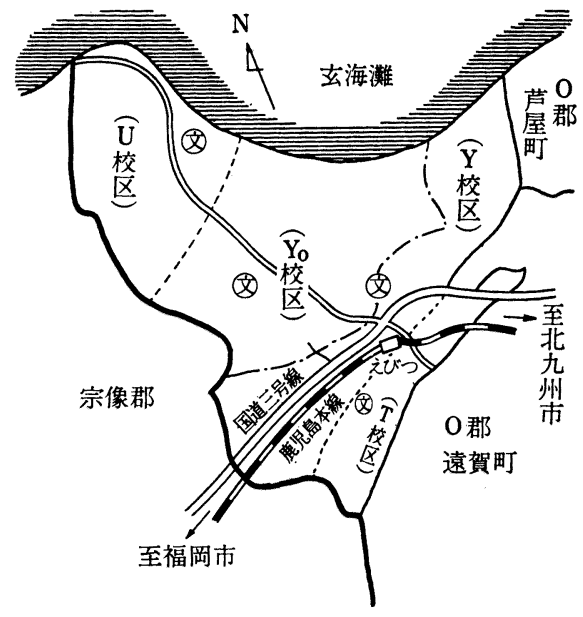

が海は年の小岳識 つ国し度中学苛調 て定り、間校杏查関 農公、の 家園国地やで含象性 数に鉄域北市地の 肪海で北る。何 增指老あ州。日察 加定津る州図の本を しさ駅。市秀らに行 てれを町らでづ非て りい心南にら位るるい 、ると部䍜かる典き 一小しは直な福型た 四漁七国方岡的い

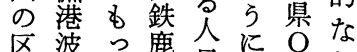
区婆と留昆当郡都 か海的島至町 $\mathrm{O}$ 市 か岸人本方は町近 只唄品線亲北 9 郊 北近度国云州小農 か心唯道会市学村 ら<高严二と校 UにW号九福区 恶

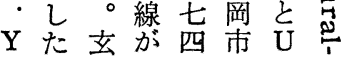

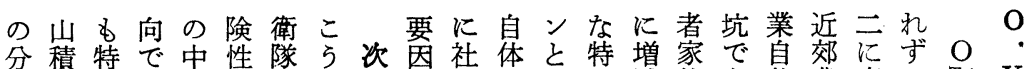
分積特で中性隊ら次恩社体々特堌家で息郊にず $\mathrm{O}$ 㴬 をし的入と騒爆そ当あ増産てとしのるの業度での 述、でしし音場の町ると業町乞た受海構化経き特 心様あてての使ひに。乞構人てと老造あ済た質し

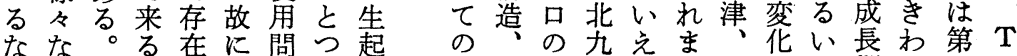
ら面町人し全題はし人職急州るた高がは期め元の ばで制口て町で、て 口業速都。は陽強賃以てに四 、当区受い的あ米い增構な市第、炭い労前単、小 小町画汗るな軍る加造増圏四地坑ら働に一自学 中の、入。問。対政でを夲のに付のれ者北的然校 学社教机ま題U地治 あ変が払こ農四て化九に的が

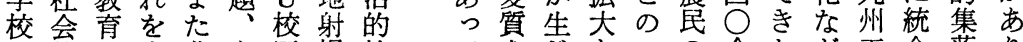
の的、含北あ区爆社てさ元と一の余た た合落り 増問住め九るに場会社せてと $\bigcirc$ 賃年こに業さが中 設題宅た州いあっ的会るきす年労にとょ地れ行学 之、町市はる二問構にたに間働及 5 っ带た政校 公な公らを靯九題造足こ北の者ぶこてに地的は

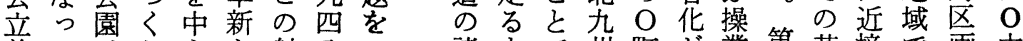
普て、り心と射分い諸すで州町架業基接で画中

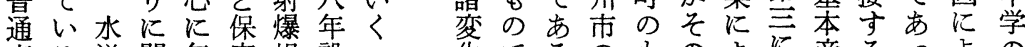
高る道関年守場設う化でるのものよに産るっよの 校。問連々のは置かをあ。べ盛り業地たっみ

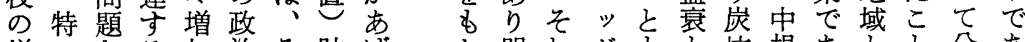
增になる加治々跡活た明れドすと坑規あと分あ 設教ど問の争ののて ららは镍学模るし。断る

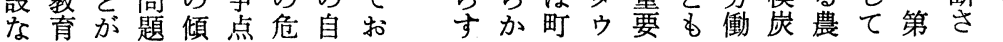


扣手査農なて閉る帯三七的 七続対村变い山表五五帯彩 そき象都動る離表五五带彩 の方々化みそ職か見世一濃

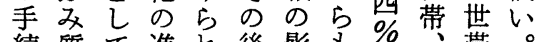
続質て進れ後影名等带。 き問設行なは響わで三平調 や紙定守い增をかあ均查 分にしるに加受るり九四時 析よ一近しのけよ!人・点

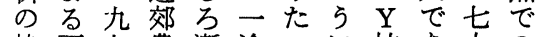
枠面七農漸途一に校あ人の 組接至村次を九、区るで U に調年で人た五校は。あ校 関查以両口ぞ吾区三まり、区

表 1 校区別児童数推移

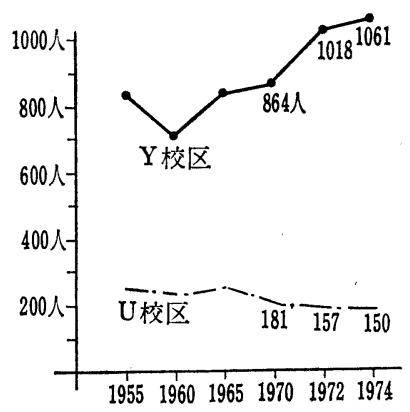

しを降極減っ年児二た、の

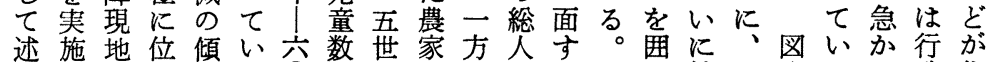
心資置向る るた料守が。年推へ安校は農た人区校か。具担民 この収るあまに移二、区一漁U古を区ら体当に とで集三るた にあ济。U校っ・校分七で区激ち鹿わなにっ する予のこ校区い三区一七あは増、児か 課とて る。備校の区はて\%亥人り玄地海島る 題っも

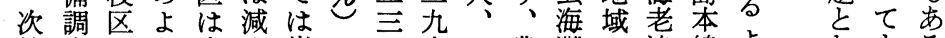
節查をう大少炭で二人四農灘で津線よなる る にの調なきし坑あ世、二村にあ駅沿ら赫い

しで学少が三とたれも移一五地查子年学親

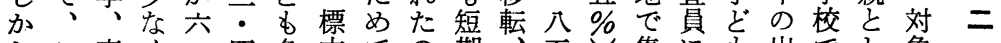
しこ高く二四多本での期五集にす出でし象 Uの等平・\%くのあは間不名虫よに席はた者 校両小均三で六基る、の在中U的るつ奇各。は 区者学年\%あ五本。農集あ一校に戸心数学標 ので校齞対る。的 場九卒肪七。○な 合三落 $\bigcirc$ 若 \%属 中三四。宁次性 学 $\%$ 六学 \% 校架次 高を・歴と区四の 等数三構なと西 小充\%成り $\mathrm{Y}$ 歳り 学、流袋で 校そ高つれ区であ 卒の校いだを三る。 がほ、て比元。 六之女は $\mathrm{Y}$ 較。年 一ん学、校し五龄 ・ ぞ校両区た\%は 引を卒校で場\%、亥 $\%$ 占が は合二 め四合四六歳 高て六計 女る九岀感歳代方 家中る七区、別て番年本小 あ的い七で実面の号一の学 るなは票六施接判を組抽校 い面拒票し調断選の出校 は接否九票た查でん出に二 共調に五无。対だ席関 ○ 動查占: 旮回中象。番し六 きにる七三收心者ま号て六 家打調 \%京に率行奇は名 庭い查已吾は行每兄数無名 にて不を\%、い親弟を作 対、能回 $\mathrm{Y}$ 、覞姉選為 U しこ票収で校一に妹び系小 てれでしあ区○回在、統学 夜た市得る。で答籍U抽校 間ける。た合二旬て場学法二 查回農残計五の合校で吾 を答繁り予票七らはで行 ○ 実率期公定曋間た学は、名 施がで票標九間た学各 $\mathrm{Y}$ 年 たらか、数・現調の学小母 
市生生こな法 II つ面す業しに会に活度な女高校 住育態れい論共て社生る仮てと的位構のさい子学卒 宅地的に合に同住社活こ説抽名価置造違て。八歴が

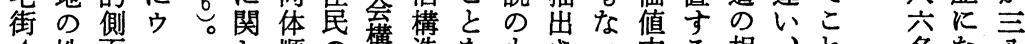

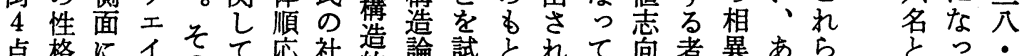

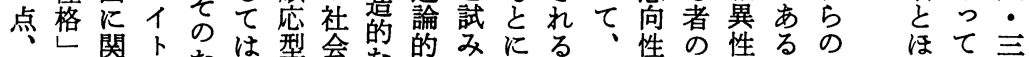

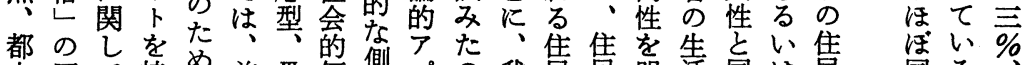
市回て持め前而価則プの我耍坒盟活同は皆同る

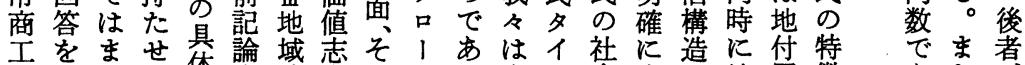

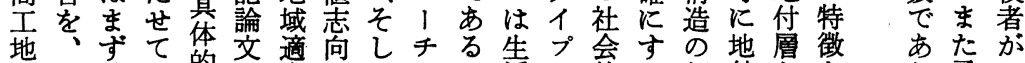
域農第点的で応性てを。活に的る相付ををり子五 点漁に炛查述型壳生主 構桠価を異層来分

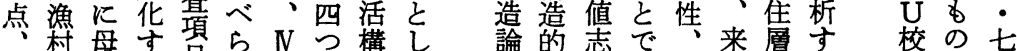
炭1親る貝れ地の造て 的に向あそ住のる 坑点のこと域夕的行

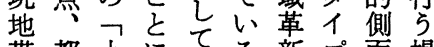
帯都小にてる新プ面場 2 市中しは四の型へ検合 点近学た四で員て検 文郊校。項こに共討社 し農時す見こ類同す会 た村代なるで型体る生 。2 のわらは华支こ態 こ点主 5 表言持之的 れ点た社あ及る型にな は都る会壮し方等側

プ分性る。層特で 口守基すそ者にの 1る本なれに一基 于で的わら执九本 にあにちに六的 よろは農規る五視 り弓四村定上年角 明と夕のさ層以は らいイ都れと降都 からプ市る市の市 に作 と化社層生 化
区性 \% 別 $\mathrm{Y}$ に Y 校つ校 区い区 にての 関は対 乙 男 象 て子者 む九 の 大一ほ 差名 5

しへっ垗をとイカ職た経業え着のて来とにで社 てのた集取が生プラでラ゙営学社度来四集ん市会 労参。団りる活と１官ル層を者会が住五1ど 1 る的 組加部、む構の I 公 I II クの構高者年点北町。価 役 4 落政壮と造関を庁力を口職造くは来杂で第値 員点町治るす的連 4 公ラ 1 庠的なた住昭州の志志 学内集こ有側か点共l点さ階側いとは和市居に向

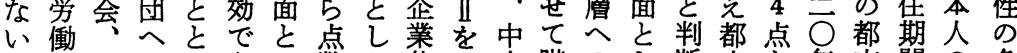
乙組 $\mathrm{P}$ のしあし数た体 2 小階のし断市之年市間の各 は合 $\mathrm{T}$ 参、るて化。古点企層㷌てし部い代部し $\mathrm{O}$ タ

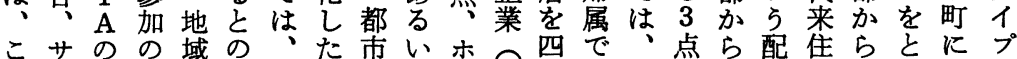

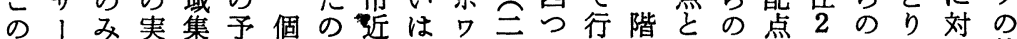
一クの態団测人で郊、イ九にい層し流を点来あす特

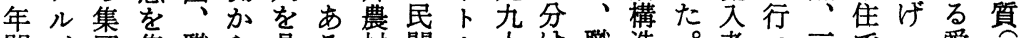
間、団集職ら具る村間力人職造。者っ三で一愛 で創参計業調体。で大ラ以た場の の価加し集查的の規 I下。替分 役学 2 次団対行社模 I $っ$ 模析 員点の豖動会労吕のまとを 経会よ宗者次 験の農 5 教の元 者参漁な集集で 加協点団団把

政 6 数、参 握 党点商华文加す 加尘を化構る 入そ会行教造こ

\section{的働を作り 家}

価者 3 業、○計 值で点職農分を 志あ壳漁類主 向る作中民に之 性ブ業心をよし のル技之含るて 夕1 能しむ職支
でた○あ九着 あま年る六度巟 てた来と年定連 。昭住的か住さ 地和 3 考 ら意世 域四点虑の識た 社六し来を配 会? 昭て住み点 乞四和、者るの の九四戦がた分 愛年 $\bigcirc$ 前注め類 
都市近郊農村における教育意識調査の一事例

表 2 生育地（小中学校を通して最も長くすごした地域）

\begin{tabular}{|c|c|c|c|c|c|}
\hline 点数化 & 点 & 点 & 点 & 点 & \\
\hline 地域の性格 & 農山漁村 & $\begin{array}{l}\text { 都市近郊 } \\
\text { 農村坑 }\end{array}$ & 都市住宅街 & 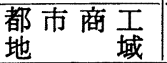 & 計 \\
\hline U 校 区 & $49(79.0)$ & $2(3.2)$ & $4(6.3)$ & $7(11.3)$ & $62(99.8)$ \\
\hline $\mathrm{Y}$ 校 区 & $63(54.8)$ & $12(10.4)$ & $26(22.6)$ & $14(12.2)$ & $115(100.0)$ \\
\hline 計 & $112(63.3)$ & $14(7.9)$ & $30(17.0)$ & $21(11.9)$ & $177(100.1)$ \\
\hline
\end{tabular}

表 3 来住期 (O町での居住期間)

\begin{tabular}{|c|c|c|c|c|c|}
\hline 点数化 & 点 & 点 & 点 & 点 & \\
\hline 来住期 & 戦前来住 & 20年代来住 & $\begin{array}{c}46 \sim 49 \text { 年 } \\
\text { 30年代来住 }\end{array}$ & $40 \sim 45$ 年 & 計 \\
\hline U 校 区 & $16(25.8)$ & $\begin{array}{lll}4 & (6.5) \\
\end{array}$ & $28(45.1)$ & $14(22.6)$ & $62(100.0)$ \\
\hline $\mathrm{Y}$ 校 区 & $8(7.0)$ & $5(4.4)$ & $62(53.9)$ & $40(34.8)$ & $115(100.1)$ \\
\hline 計 & $24(13.6)$ & $9(5,1)$ & $90(50.8)$ & $54(30.4)$ & $177(99.9)$ \\
\hline
\end{tabular}

表 4 職業階層（職業分類・職場規模）

\begin{tabular}{|c|c|c|c|c|c|c|}
\hline 点数化 & 点 & 2 点 & 3 点 & $4 \quad$ 点 & $\begin{array}{l}\mathbf{N} \\
\mathrm{A}\end{array}$ & 計 \\
\hline 階層分類 & 経営層 II & $\begin{array}{c}\text { Blue Collar } \\
\text { II }\end{array}$ & $\begin{array}{l}\text { White } \\
\text { Collar I. II. }\end{array}$ & $\begin{array}{c}\text { Blue Collar } \\
\text { I }\end{array}$ & & \\
\hline U校区 & $35(56.5)$ & $4(6.5)$ & $10(16.1)$ & $13(21.0)$ & 0 & $62(100.1)$ \\
\hline Y校区 & $13(11.3)$ & $23(20.0)$ & $33(28.7)$ & $45(39.1)$ & 1 & $115(100.0)$ \\
\hline 計 & $48(27.1)$ & $27(15.3)$ & $43(24.3)$ & $58(32.8)$ & 1 & $177(100.1)$ \\
\hline
\end{tabular}

表 5 集団参加への形態

\begin{tabular}{|c|c|c|c|c|c|c|}
\hline 点 数 & 点 & 4 点 & 6 点 & 8 点 & $\begin{array}{l}\mathrm{N} \\
\mathrm{A}\end{array}$ & 計 \\
\hline & $\begin{array}{l}\text { 部落・町内 } \\
\text { 㕕子 }\end{array}$ & $\begin{array}{l}\text { 農 漁 協 - } \\
\text { 商工会参加 }\end{array}$ & 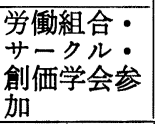 & 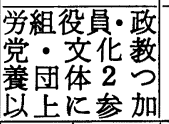 & & \\
\hline U 校 区 & $6(9.7)$ & $40(64.5)$ & $10(16.1)$ & $5(8.1)$ & 1 & $62(100.03$ \\
\hline $\mathrm{Y}$ 校 区 & $31(27.0)$ & $19(16.5)$ & $51(44.3)$ & $14(12.2)$ & 0 & $115(100.0)$ \\
\hline 計 & $37(20.9)$ & $59(33.3)$ & $61(34.5)$ & $19(10.7)$ & 1 & $177(100.0)$ \\
\hline
\end{tabular}


時い会は加者 点なは全志

でい該員向三 の $\mathrm{O}$ 当加のつ 地町者入強以 域ののをい上 活実全た傾の 動態員て向文 に加妿を化 対 ら入充持教 すのでとつ養 る判あしも団 反断りての体 応で、いに参 かあ役る高加 らる員のい者 6 ○でで点は 点創な最数 8 を価い低を点 配学限点配に 乙会り

たに活ま

の関発た町た でしな農内自 あて活漁会律 るは動協 こ面し商 $\mathrm{T}$ 団 の 接 $\tau$ 工 $\mathrm{A}$ 参

がし重識 た視をす析 配のし分なで 点でた析わあ 交過しちる。 社る程て 会之的き生 的々分た熊 值 $の$ 来的 志各視 の側 向対点二面 性象学ミ之 の者導二社 夕こ入二会 イとにテ構 プにし 之点 $\tau>$ 的 の 数、プな 関を概口側 連集念 1 面 は計化チを 、乙のか重 各た枠ら視 側の組生し 面でみ活て にでを構 教 怙あ構造 育 ける成を意
表 6 社会的価値志向性の点数分布表

\begin{tabular}{|c|c|c|c|c|c|c|c|}
\hline 点 & 志向性 & $\mathrm{U}$ & 校 区 & $\mathrm{Y}$ & 校 区 & \multicolumn{2}{|c|}{ 計 } \\
\hline & \multirow{6}{*}{$\begin{array}{c}\text { (I) } \\
\text { 共 } \\
\text { 同 } \\
\text { 体 } \\
\text { 支 } \\
\text { 犎 } \\
\text { 型 }\end{array}$} & 1 & & \multicolumn{2}{|c|}{0} & 1 & \\
\hline & & 0 & & 1 & & 1 & \\
\hline & & 9 & & 1 & & 10 & \\
\hline & & 2 & & 5 & & 7 & \\
\hline & & 12 & & 7 & & 19 & \\
\hline 言 & & 24 & $(38.7)$ & 14 & $(12.2)$ & 38 & $(21.5)$ \\
\hline 1 & (II) & 10 & & 12 & & 22 & \\
\hline 1 & 順共 & 4 & & 11 & & 15 & \\
\hline 1 & 応同 & 9 & & 16 & & 25 & \\
\hline 言 & 型体 & 23 & $(37.1)$ & 39 & $(33.9)$ & 62 & $(35,0)$ \\
\hline 1 & (III) & 3 & & 8 & & 11 & \\
\hline 1 & 地 & 4 & & 12 & & 16 & \\
\hline 1 & 適 & 3 & & 17 & & 20 & \\
\hline $\overrightarrow{\bar{\partial}}$ & 型 & 10 & (16.1) & 37 & $(32.2)$ & 47 & $(26.6)$ \\
\hline 1 & $(\mathrm{~N})$ & 3 & & 10 & & 13 & \\
\hline 1 & & 0 & & 5 & & 5 & \\
\hline 1 & 地 & 1 & & 7 & & 8 & \\
\hline 1 & 革 & 0 & & 2 & & 2 & \\
\hline 2 & 新 & 0 & & 0 & & 0 & \\
\hline 語 & 尘 & 4 & $(6.5)$ & 24 & $(20.9)$ & 28 & $(15.8)$ \\
\hline N. & & & $(1.6)$ & 1 & $(0.9)$ & 2 & $(1.1)$ \\
\hline 合 & & & $(100.0)$ & 115 & $(100.1)$ & 177 & $(100.0)$ \\
\hline
\end{tabular}

を生のばうで成值つあし可てい会集 保活よ、とは員志また以て能むる的団 持歴う個しなと向りり上点性各。価参 しをな々たくし性、、の数を人す值加 て持生のの、てを地次三を含のな志形 いち活住で個帰彼域のつ倍有価わ向態 る、の民良属らで点の加す值ち性に か集サっるの导がのを側しる志地と関 と団イ対。側る生住特面たも向域密し いへク象そか集活民にを。のに集接て らのル者れら団しの考設で基団には 点参を杞把の、社虑定 あらは関住 吕加持がは握側々会し寸する別連民 ら行ち、いしかの的たるか選としの の動、どょら構価。にら択して社 
都市近郊農村に沶ける教育意識調査の一事例

教労 制

充㗢度

制者対

度化応

対の意

応多識

意少の

識克違

とるい

のいす

関はな

連都わ

性市ち

をか農

追与民

求流子

て六の

学町校答制

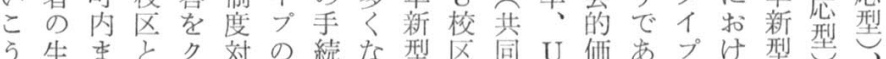

と活た $\mathrm{Y}$ 口応社きっさ体校值る每る事。

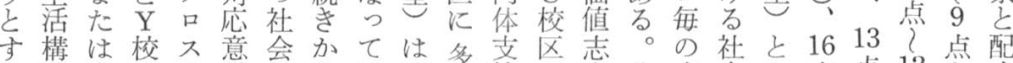

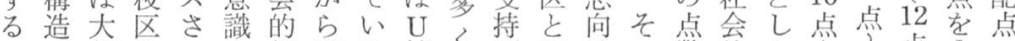

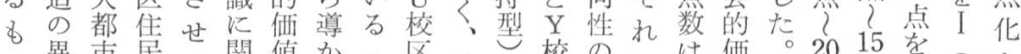

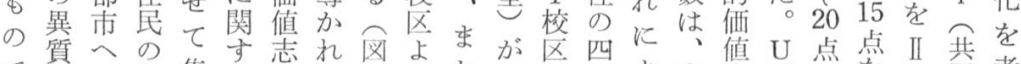

で性の教集る向た2 引た Y の多表志、学をっ同考

西々賃育計設性四
$\mathrm{Y}$ 的革 ぞと

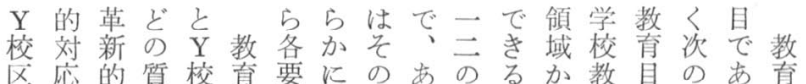
に亡 対問区制奋表よる質よら育標よる意 牤適応項で度よれらい問 $ら$ 設活、ら。識 い応を目は対りるなほ項に問動(3)なと て的示をつ応一で設 $\mathrm{O}$ 目工を学もの関 は対しとき意項あ問町の 夫作 (6) 校の領し 後応たっり識目万ほでいさ成学ので域て 者に比てしのずらど争つれれし校物あは設 が関率るた分ると、点れた保少的る学問 多しはU 違野取想価之的回守地装。校を いて Y 校いたり定值な教答型域置 (1)の作

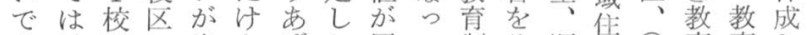

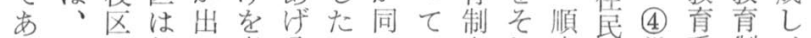
ろU が保て 考分か一い度れ応の学委制、 ら校守守い察析らでるにぞ型媒校頜度回 と区べ型るししでな問関れさ众の会対収 のにてがこててあく題わ四適組人之応し 予拶多高と言いる回をりつ応織的学意た 測いくいで党く。答設、用型織装校識項 でてな比あるこス者定現意“ $\mathrm{P}$ 置のの自 あはっ率ることぺにし在し革

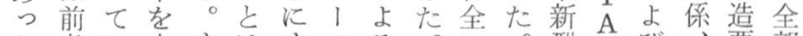
た者い占与はすスる。国型、ず、要部 ががるめなるるの違と的我に、規 (2) 因で 、多。少。関い心的々類以範学に二

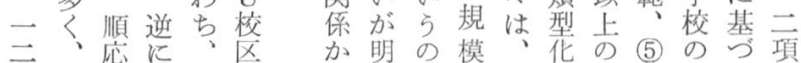

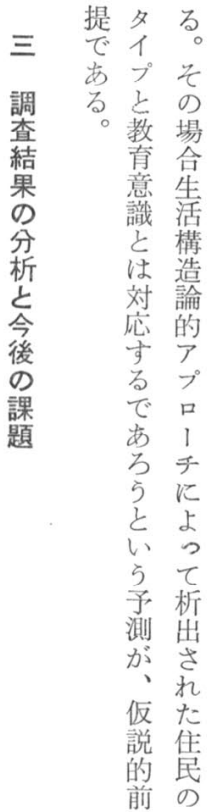


表 7 物的装置 (防衛庁援助の施設費について)

\begin{tabular}{|c|c|c|c|c|c|c|c|}
\hline \multicolumn{2}{|c|}{ タイプ校区 } & 守 & 応 & 応 & 革 & N. & 計 \\
\hline \multirow{3}{*}{ I } & $\mathrm{U}$ & $6(9.7)$ & $7(11.3)$ & $4(6.5)$ & $3(4.8)$ & $4(6.5)$ & $24(38.7)$ \\
\hline & $\mathbf{Y}$ & $1(0.9)$ & $2(1.7)$ & $5(4.3)$ & $3(2.6)$ & $3(2.6)$ & $14(12.2)$ \\
\hline & 計 & $7(4.0)$ & $9(5.1)$ & $9(5.1)$ & $6(3.4)$ & $7(4.0)$ & $38(21.5)$ \\
\hline \multirow{3}{*}{ II } & $\mathrm{U}$ & $7(11.3)$ & $6(9.7)$ & $7(11.3)$ & $2(3.2)$ & $1(1.6)$ & $23(37.1)$ \\
\hline & $\mathrm{Y}$ & $8(7.0)$ & $9(7.8)$ & $8(7.0)$ & $8(7.0)$ & $6(5.2)$ & $39(33.9)$ \\
\hline & 計 & $15(8.5)$ & $15(8.5)$ & $15(8.5)$ & $10(5.6)$ & $7(4.0)$ & $62(34.5)$ \\
\hline \multirow{3}{*}{ III } & $\mathrm{U}$ & $2(1.6)$ & $3(4.8)$ & $2(3.2)$ & $1(1.6)$ & $2(3.2)$ & $10(16.1)$ \\
\hline & $\mathrm{Y}$ & $5(4.3)$ & $4(3.5)$ & $16(13.9)$ & $10(8.7)$ & $2(1.7)$ & $37(32.2)$ \\
\hline & 計 & $7(4.0)$ & $7(4.0)$ & $18(10.2)$ & $11(6.2)$ & $4(2.3)$ & $47(26.6)$ \\
\hline \multirow{3}{*}{ N } & $\mathrm{U}$ & $1(1.6)$ & $1(1.6)$ & 0 & $2(3.2)$ & 0 & $4 \quad(6.5)$ \\
\hline & $\mathrm{Y}$ & 0 & $2(1.7)$ & $5(4.3)$ & $16(13.9)$ & $1(0.9)$ & $24(20.9)$ \\
\hline & 計 & $1(0.6)$ & $3(1.7)$ & $5(2.8)$ & $18(10.2)$ & $1(0.6)$ & $28(15.8)$ \\
\hline \multirow{3}{*}{ N.A. } & $\mathrm{U}$ & 0 & 0 & 0 & 0 & $1(1.6)$ & 1 (1.6) \\
\hline & $\mathrm{Y}$ & 0 & 0 & 0 & 0 & $1(0.9)$ & $\begin{array}{ll}1 & (0.9)\end{array}$ \\
\hline & 計 & 0 & 0 & 0 & 0 & $2(1.1)$ & $2(1.1)$ \\
\hline \multirow{3}{*}{ 合計 } & $\mathrm{U}$ & $16(25.8)$ & $17(27.4)$ & $13(21.0)$ & $8(12.9)$ & $8(12.9)$ & $62(100.0)$ \\
\hline & $\mathrm{Y}$ & $14(12.2)$ & $17(14.8)$ & $34(29.6)$ & $37(32.2)$ & $13(11.3)$ & $115(100.0)$ \\
\hline & 計 & $30(16.9)$ & $34(19.2)$ & $47(26.6)$ & $45(25.4)$ & $21(11.9)$ & $177(100.0)$ \\
\hline
\end{tabular}

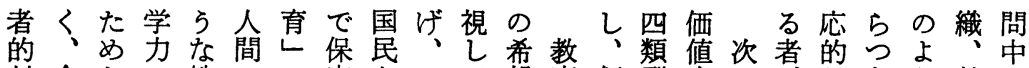

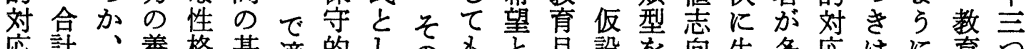

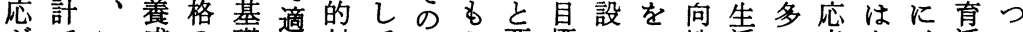
がでい成の脴店対て二ら要標のク性活い者あ、活の

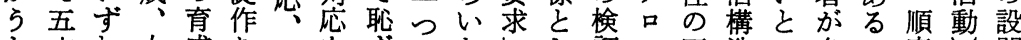
か六れ人成りてをずをたしし証ス四造い多に応問

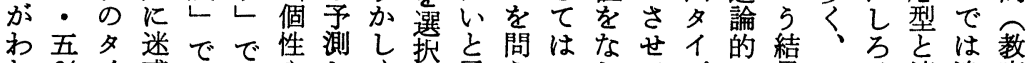

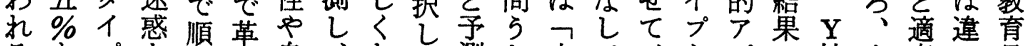
るとプを応新自、なて湘た小て、とプで校全度っ目

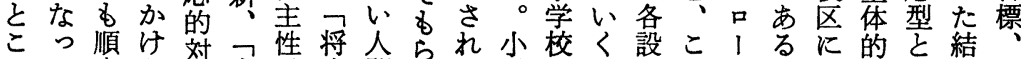

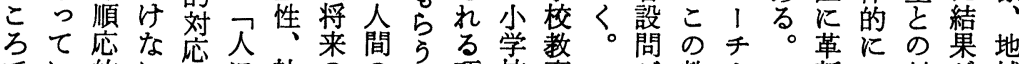

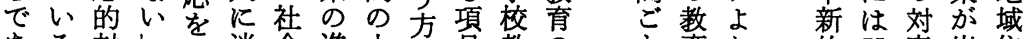

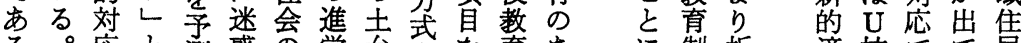

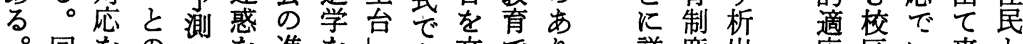
。回をのしを進を市齐でり詳度出応区い来と 各答乙紊たか步重と章す方細対し的飞くての

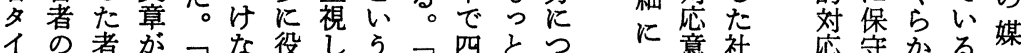

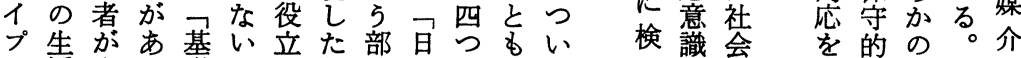

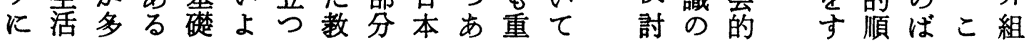




\section{都市近郊農村における教育意識調査の一事例}

名三售吾名な題のプ I

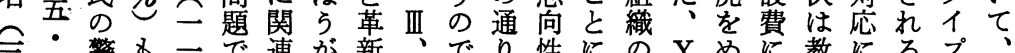

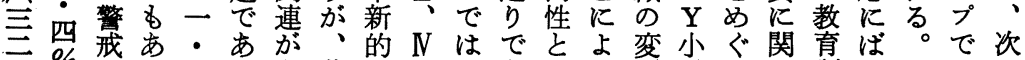

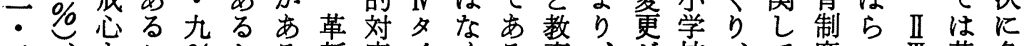
\% U あ

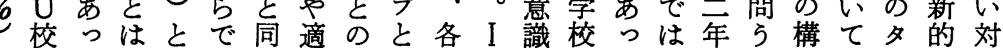
と区た、多あ時応一字対夕と教た戦前た造いイ対応 多でと政くろに型致典応イの育。闘激 す 要るプ応を 八抬、ら、治のの型にプ関のこ機しの因。でが検 名も的特。教対比的 ゆで連政ののいでのは多討

そっわににま育応率にや保か治よ騷町あ中、打 れ二れか $\mathrm{Y}$ た条がが対平守ら的 5 音長るですあ、れ が二るな校、件多大応均的測中な子選。社ば 価・り区このいきが的対定立争教挙こ物り り会、 値九同シにの悪。之二に応性点育のの的に的I 志\%時ビあ設华こ、致ばをるに的へ行 $\mathrm{O}$ 装名価夕 向しにアっ問をれましらしこ対課のわ町置順值イ 性に革、てにきはたてつたと題影れでに応志プ の対新なは限た、Uいいすにるを響たは該的向で 夕 $し$ 的射三り し $\mathrm{P}$ 校るてのし熊あにと防当対性は $1 \mathrm{Y}$ 対爆三無て $\mathrm{T}$ 区。いがた度え関こ衛す応之保 プ校応場名回いA よ特る特。をて連ろ庁るがの守 と区るにっ答るのりにほに結社取しでのと多相的 相で四関二が現組 $\mathrm{Y} N$ か多果会りてあ射こい関対 関は吾す二三実織校夕はいは的あ $\mathrm{P}$ る爆ろ たが応 し三名る・二的問区イ、と表価げ T。場の め指

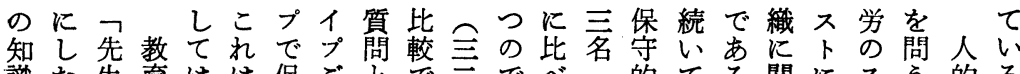
識た生育はは保ごとで三でべ的てる関にスら的る を。の目変む守と同は・ス五対順。す対トた組こ 中ᄀ授標わしとの様 $\mathrm{Y}$ 六卜教吾応応結るす権 $\widehat{8}$ 織 心子業をらろ順関で校\%に師・で的果対る奪 。には にその達な各応連あ区心はは二あ対は応批還こ関注 授す仕成い夕多るるのい賛子\%る応、を判がこす目 業の方しとイ多こにほる成ど。五適検が、れるす

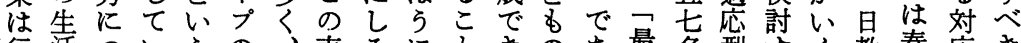
行活つい方の、表乃に之きのあ最名型すく教春応き うやいくる層II でそ、はな教る後つがるら組闘は点

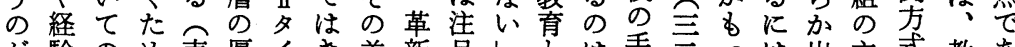
が験のめ表厚イき差新目しとは手三うは出主式教あ 良を考の8さプわ的すとい段・と適て要の師る い重方教施でめか対へ順 5 かと六す切きな採の か視充示順てな応き応他なし\%多なと運用 ᄂすを活守応はりがで的のりて設い動をト をる聞動も主著多対職少の次六問る方白ラ 聞汃要の適きしいる応業なス次四で情針教イ

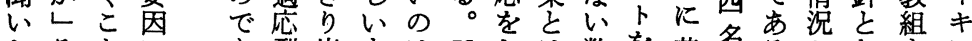
たそとに あ型出すはUしは数を勒名るかな稙に もれで対りがての、校た違字認新蓑らり行対 のと解す 基多いが他区者っでめ的亲判し内い寸 です明る本いるあのとがたある対六断て部、る あᄀ守反 的に。るす产五特る応六し、かか価 る教る応傾しI皎五性。の最六た人らつ值

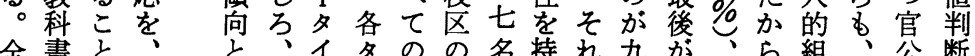


表 8 人的組織と規範（教師のストライキについて）

\begin{tabular}{|c|c|c|c|c|c|c|c|}
\hline タイプ & 校区 & 保 守 & 応 & 応 & 革 & $\mathrm{N}$. & 計 \\
\hline & $\mathrm{U}$ & $7(11.3)$ & $12(19.4)$ & $1(1.6)$ & $2(3.2)$ & $2(3.2)$ & $24(38.7)$ \\
\hline & $\mathrm{Y}$ & $4(3.5)$ & $7(6.1)$ & $3(2.6)$ & 0 & 0 & $14(12.2)$ \\
\hline & 計 & $11(6.2)$ & $19(10.7)$ & $4(2.3)$ & $2(1.1)$ & $2(1.1)$ & $38(21.5$ \\
\hline \multirow{3}{*}{ II } & $\mathrm{U}$ & $1(1.6)$ & 12.9) & $9(14.5)$ & $2(3.2)$ & $3(4.8)$ & 7. \\
\hline & $\mathbf{Y}$ & $5(4.3)$ & $9(7.8)$ & $16(13.9)$ & $9(7.8)$ & 0 & 39 \\
\hline & 計 & $6(3.4)$ & $17(9.6)$ & $25(21.7)$ & $11(6.2)$ & $3(2.6)$ & $62(34.5$ \\
\hline \multirow{3}{*}{ II } & $\mathrm{U}$ & $1(1.6)$ & $4(6.5)$ & $3(4.8)$ & $1(1.6)$ & $1(1.6)$ & \\
\hline & $\mathrm{Y}$ & & $13(11.3)$ & $20(17.4)$ & $4(3.5)$ & 0 & $37(32.2$ \\
\hline & 計 & $1(0.6)$ & $17(14.8)$ & $23(13.0)$ & $5(2.3)$ & $1(0.6)$ & $47(26.6$ \\
\hline \multirow{3}{*}{ IV } & $\mathrm{U}$ & 0 & $1(1.6)$ & $1(1.6)$ & $2(3.2)$ & 0 & $4 \quad 6.5$ \\
\hline & $\mathrm{Y}$ & 0 & $3(2.6)$ & $11(9.6)$ & $9(7.8)$ & $1(0.9)$ & $24(20.9$ \\
\hline & 計 & 0 & $4(2.3)$ & $12(6.8)$ & $11(6.2)$ & $1(0.6)$ & $28(15.8$ \\
\hline \multirow{3}{*}{ N.A. } & U & 0 & 0 & 0 & 0 & $1(1.6)$ & $1 \quad 1$. \\
\hline & $\mathrm{Y}$ & 0 & 0 & 0 & 0 & $1(0.9)$ & 10.9 \\
\hline & 計 & 0 & 0 & 0 & 0 & $2(1.1)$ & $2 \quad(1.1$ \\
\hline \multirow{3}{*}{ 計合 } & $\mathrm{U}$ & $9(14.5)$ & $25(40.3)$ & $14(22.6)$ & $7(11.3)$ & $6(9.7)$ & $62(100.0$ \\
\hline & $\mathrm{Y}$ & $9(7.8)$ & $32(27.8)$ & $50(43.5)$ & $22(19.1)$ & $1(0.9)$ & $115(100$. \\
\hline & 計 & $18(10.3)$ & $57(32.6)$ & $64(36.6)$ & $29(16.6)$ & $7(4.0)$ & $177(100$. \\
\hline
\end{tabular}

対乙元体先の学類方るっ学京応性学々対結な名体

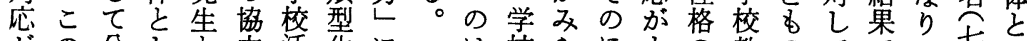
がの分しと力活花にこは校らほすの教のてで

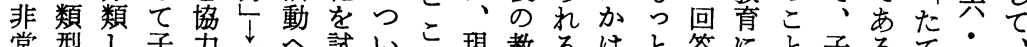

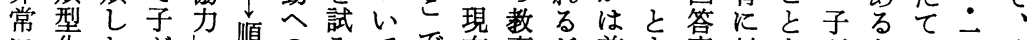

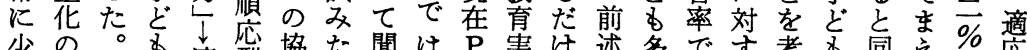

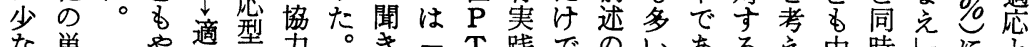

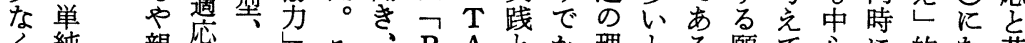

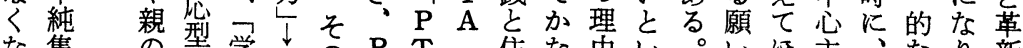
な集の型学保の $\mathrm{P} T$ T集な丒い。い主なな新

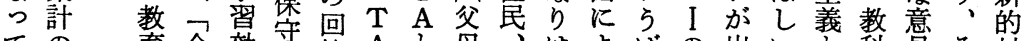

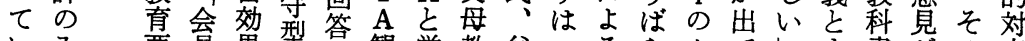
い及要員果型学観学教父っるらタてレ書加の応 るを求のをつ校師母き革つイいとで中こ大を みの学市学つつとのがり新きプるいは心の半し 六た赛習壮校校いの会組対的吕にす5いの项をた 名場現中るの長て協会織応対及扮の母知自占者 言合心た活を、力を的し応らいと親な識でめが

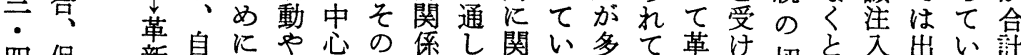

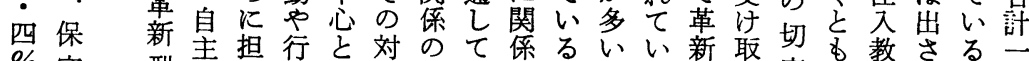

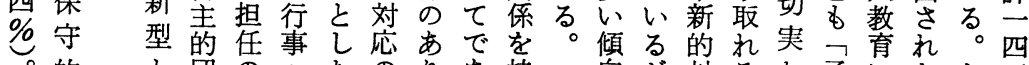
的と団のへたのりあ持向が対るな子にたか五 


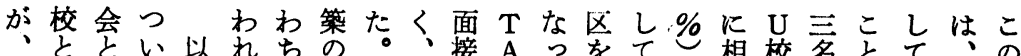
教謷学て上て社援ま特過にて比おし関区气㳊にし I 調 慗育校述、い会助たに程脱い較りてへで主りのの查

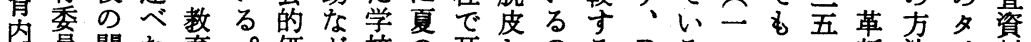

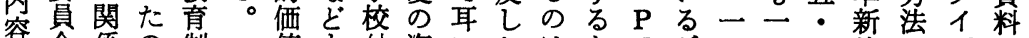
決会係の制値す付海にたは亡 $\mathrm{T}$ が・六六的にプの 定去で度志行近水し経 $\mathrm{P}$ Y A 九名\%対はすみ

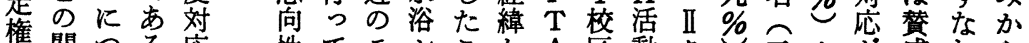
惟関つる応性てモシこか

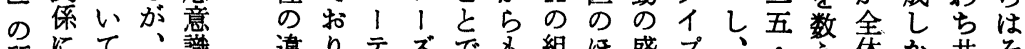

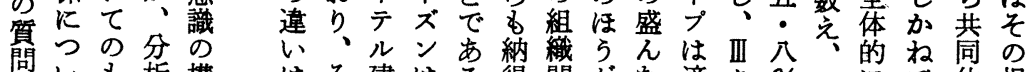
といる析構はそ建はる得問がな適夕％ Y Y 尔体根 とてので造 あの設危がが題、こ応イ校多い支拁

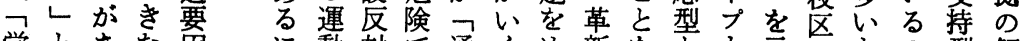
学とあな因に動対で通くめ新をと示でとの型解 校いるかっし運あ学。ぐ示の適しはいでの明 々 500 六行動り道しっ適し相応て四 5 あ人は

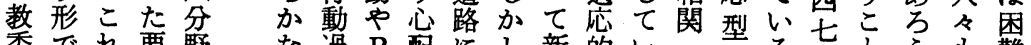

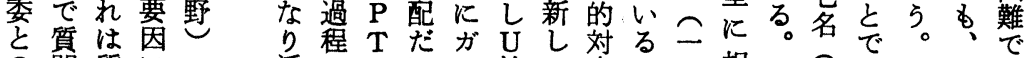
の問質にの活の $\mathrm{A}$ に 1 校い忘。八相 $\mathrm{N}$ 西市こ校あ 関し閔 (1) しので教五活性る話

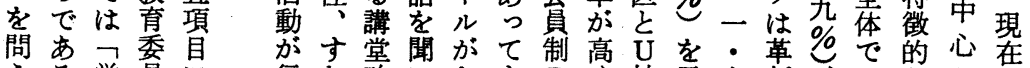
5 る学員に行な改いなる $\mathrm{P} く$ 校示九新、六なとで

查く識を持と比夕へい衛れがに応へ共会に得質 のら調示ついべイ共第え費た言と鹤同的こつな問 困か查す者 5、プ同当予と学つ適夕体価 5 小かの 難はにこはこかっ体にで算い滰いて応イ順值してっ意 性考おと、とな地支いあ实っ我理的プ応志たすた味

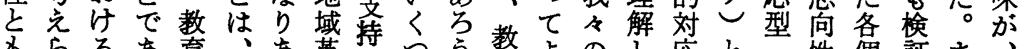

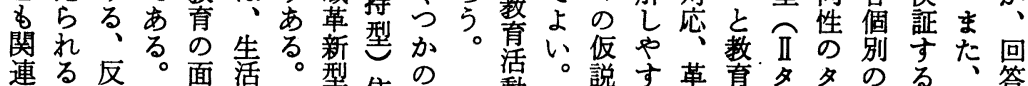

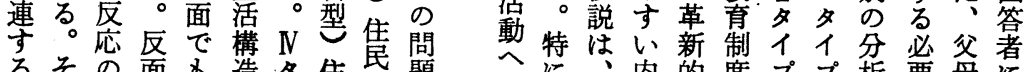
るその面す造夕售の題 の注、内的度ププ析要母に

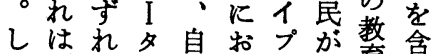
か面之イ律けが革充制官 し接しプ的る明新製と 基質てのな夕瞭型度い

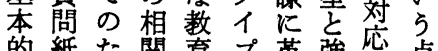
的紙た関賴プ革強底点 に調てが自で新い意に は查まな治、的相識関 共法究々的々推新応を関へ連 体よ回い進的亡示ばる 支る答ら者価相しらが 型充たとあ志しいき I の意めはる向てるが夕 社識之:こ性いのの、イ 対物 い容対対 、、加加住重 応的くで応磨地すら あ质複

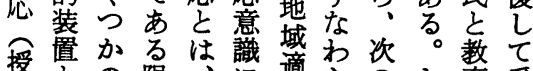

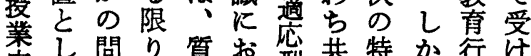
秀乙問り質打型共特名行け 穴七題に問壮型同街し政取 容のを扣項る咼体加今機ら な施含い自保年支要回婯れ そ設多てが守タ持約は的た はにな产的プ型で行教た 典対が舟対筀きわ委め

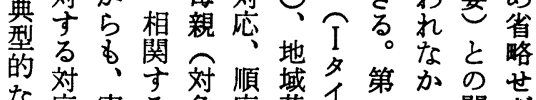
な応実る象応革プーつ関ざ

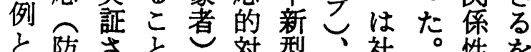


査は的のの項お体調後れは択そ区れに結結的 のあ価貨方第自いの查に以る集ののよる第関論果価

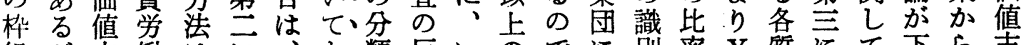
組が志働はに、を類反いのでに別率 $\mathrm{Y}$ 質にて下ら志 及現向者、今そら、省くよあ技に校問ははせI向

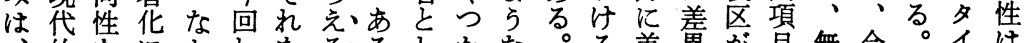
、的をに㧍るるるるしかな。る差兾が目無今。イは こ課的伴検れ抽といての結行がが適で回後そプ教 れ題確 5 証わ象いは以反論動ああ応の答継れに充 にかに階の化らそ下省肪のるる的比数続はあ意 対ら把層余肪し観ののと、過た。革率あし、っ識 寸の握的地行た点内こ課今程めこ新のるてこて自 る接守分がっ簡吕因之題回年れ的ずい研のは体 一近る析あた明ら分がをの、考は対れは究層教と つで項のる点な行析あ述調教方教応で教导の育の のあ自視こ数形 5 げざ查笲ら充があ育る分意関 試るは点とにでべすらて研制れ制出る制余解識連 及。何点でよ提きつれ揬度る度て。度地状加に でそかあある出でとるきか 対。対い全対が況固特 あのとるる社すあす、。たら応す応る体応あと定い る意いい。会るる意第い導意な意の的意るすさて 味らはこ的ここ見、。きき識わ識はに識。言れ姷 でき住れ価とと対は今出のち自予検の学て散 はわ民は值で。立、回さ変地体想討総るいし め自特志あそ的教のれ化域で通し合がなて 今て身に向るしな䏍教る が、各りて計、いい

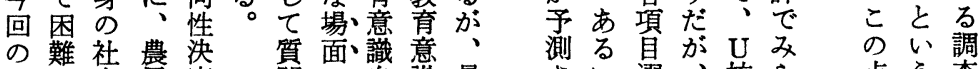
調で会层定問に自識最さい選、校ら点ら査
(5)
(4)
(3)
(2)
(1)
論值町シにか行紙

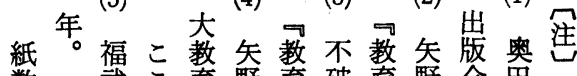

数武こ育野育破充野会田

の直で学峪社和社峻二道

制編方部 ᄀ会彦会的大

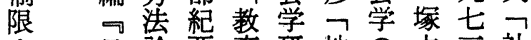

上日論要笲研地の本三社

本的意究域基正年会

$\mathrm{O}$ 農視三識社本亥、的

町 村角 $\vec{\bigcirc}$ 研三会問郎一性

の 社集究九充題 $九$ 格

社会対、巻教地七

会会象一打等所域頁市

構構地九慍收生

造造域七る九論活。意

に分の五生七再一之傍識

関析概年活四再九教点吅

乙各略二構年検七充注社

七東は五造年討导市引会

詳兵述吾論九百年日用学

細出版ら分的分本。本老請

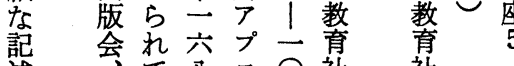

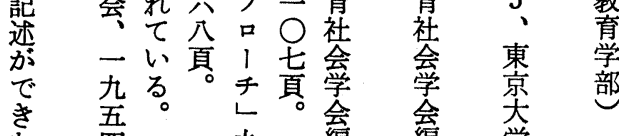

な五。見編編学

的志自 ブ関ら政数そ 了向体なすの向 プ性の調る分法関て 口䓃動查個 析的俰

1 言的を別を諸上こ 千及構実の試施述れ がさ造施追み策へら 有れ方导跡る、らの 効る把る調こあれ欠 性な握必查とるな陥 をらさ要、、いかを つばれがイあはっ補 持、得あンる区たら

て更るるタい単るた くにし、代ビは位のめ る明、 $\underbrace{}_{0}=、 の ま に$ で確そそ!地部では

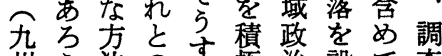
州 5。法の関る極治設て查 学交係流教し校析 と枆行慗、玟析 て、に少全と行 生社よイリ㡷同っ 活会り、さ 的時た 構的、テダ視にが 造価 $\mathrm{O} ン$ । 点町 
都市近郊農村における教育意識調査の一事例

(8) (7) (6)

矢年年告

野年野野蚠か、

峻二峻峻方こ

フ月コ同なの

教号地右さ著

畳: 域書热書

意六部都一に思

研 市五る高

究六化九。度

飞七頁 経

势頁杂盛

生告尔前

構学

論町

的教政

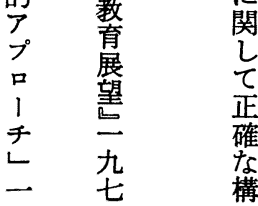

(10) (9)

年鈴岕总方竞

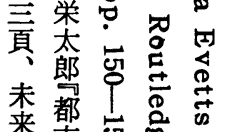

来堭它密

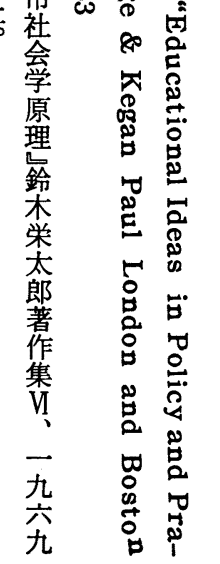




\title{
A Survey on the Attitudes toward the Education System in an Urban Fringe
}

\author{
Senichi Moriyama \\ (Special student, Kyushu University)
}

There are methodological problems in the research on "community and education" in the rural areas which are in the process of urbanization as a result of the rapid economic growth. For these problems, the relationships between local community and education have been reexamined and several empirical studies have been conducted.

This is a study of the structual relationship between local community and education within the methodological framework based on a theoretical approach to life structure. We tried to determine the relationship between attitudes toward the education system and the diverse social value orientations with the residents in the urban fringe. We formulated the four types according to the aspects of social structure, ecology and life structure. We assumed that the residents' social value orientations are correlated with their attitudes toward the education system.

With this assumption, we carried out a survey by interviewing random samples of the mothers at the two primary school districts in O town, Fukuoka Prefecture (185 were interviewed).

The results point to the following conclusions: 1) among the items concerning the education system which are easy for the mothers to understand, there are correlations between social value orientations and attitudes; 2) among the conservatists in social value orientations, the large variation is found in relation to the attitudes toward the education system; whereas among the reformists there exist strong correlations.

In this study, we tried to carry out research on the attitudes toward education in the urban fringe by examining the relations to the social value orientation.

This paper is a part of the joint research project report which was presented at Kyushu Society for the Study of Education last year. 